\title{
Biotechnological potential of by-products of the Brazilian animal protein industry in the generation of xenogeneic biomaterials for bone regeneration
}

\author{
Igor Iuco Castro-Silva ${ }^{1,2 *}$,Jesus Alberto Perez Guerrero ${ }^{1}$, Maria Janaína Paula Gomes ${ }^{1}$ and Men de Sá Moreira de Souza Filho ${ }^{3}$ \\ ${ }^{1}$ Postgraduate Program in Biotechnology, Federal University of Ceara (UFC), Avenida Maurocelio Rocha Pontes 100, 62042-280, Sobral (CE), Brazil \\ ${ }^{2}$ Faculty of Dentistry, Federal University of Ceara (UFC), Rua Conselheiro Jose Julio, s/n, 62010-820, Sobral (CE), Brazil \\ ${ }^{3}$ Brazilian Agricultural Research Corporation (EMBRAPA), Rua Doutora Sara Mesquita, 2270, 60511-110, Fortaleza (CE), Brazil
}

Biotechnological development, started in the 1950s and markedly accelerated since the 1990s, has brought significant advances in the use of biomaterials in treatments for bone loss. Study in Brazil have shown that the use of biomaterials for bone regeneration including grafts and membranes is a frequent practice among dentists of which $42 \%$ have already done grafts, especially with xenogeneic (33\%) followed by autogenous (30\%) and alloplastic (23\%) materials. In their perception, there was high professional-patient satisfaction, absence of associated morbidity and moderate surgical procedure cost [1].

Adequately treated xenografts have physicochemical characteristics and favorable biological behavior to bone repair, functioning as cellular scaffolds with high biocompatibility, low antigenicity and moderate to high biodegradability; proving to be safe and applicable, with satisfactory clinical predictability [2,3]. Furthermore, animal products could contribute to the green industry, generating economic value, sustainability and a higher quality of life, due to lower waste disposal and environmental stressors [4].

In the following work, it's presented a brief integrative review on the outlook for obtaining animal raw materials for potential biotechnological application of xenografts in Brazil through technical reports thru 2017 consolidated technical reports from of the Brazilian Animal Protein Association [5], Brazilian Meat Exporting Industries Association [6] and Brazilian Fishery Association [7], besides original articles retrieved from the Pubmed database using the keywords "bone graft AND brazil AND poultry, bovine, porcine OR fish" from 2013 to 2018 [8]. The results showed that in 2017, Brazil was one of the major producers of animal protein worldwide. For example, the Brazilian poultry industry produced 12.9 Million tons (Mt) of animal protein, the second largest producer in the world [5]. On the other hand, 9.1 Mt of cattle were produced, being also the second in the world [6], while the production of pork was 3.7 Mt, fourth in the world [5], and the fish was $0.7 \mathrm{Mt}$, fourth largest in tilapia [7]. However, the Brazilian scientific research on bone xenografts is equivalent to only $2 \%$ of the whole world and emphasize cattle derivates [8].

Due to the massive generation of by-products by the animal protein industries, there is high interest in the use of cattle [9-11], pig [12] or chicken bones [4] and fish teeth [13] to obtain hydroxyapatite as well as cattle tendon $[10,11]$, chicken [4] or fish skin $[2,13]$ and porcine intestinal submucosa or peritoneum [12] to obtain collagen type I which could generate biomaterials with bone morphofunctional mimicry being applicable to bone regeneration [10].

Given this reality, it is necessary to increase the strategic partnerships between private companies and universities in translational studies to broaden the perspective of the current investigation and be able to develop innovative xenogeneic biomaterials for bone regeneration applicable in oral surgery.

\section{Acknowledgments}

Our special thanks to Brazilian Agricultural Research Corporation (EMBRAPA-CNPAT) for the technical-scientific partnership, Coordination for the Improvement of Higher Education Personnel (CAPES-DS and PROAP-UFC-PPGB grants, Brazil) and Ceara State Foundation of Support for Scientific and Technological Development (FUNCAP, process \#BP3-0139-00270.01.00/18, Brazil) for the financial support.

\section{References}

1. Castro-Silva II, Coutinho LACR (2013) Use of bone grafts in dentistry: profile of dentists from Niteroi/RJ. Rev Bras Odontol 69: 154-158.

2. Yamamoto K, Igawa K, Sugimoto K, Yoshizawa Y, Yanagiguchi K, et al. (2014) Biological safety of fish (tilapia) collagen. Biomed Res Int 2014: 630757. [Crossref]

3. Castro-Silva II, Zambuzzi WF, Granjeiro JM (2009) Current overview of the use of xenograft in dentistry. Innov Implant $J$ 4: 70-75.

4. Dias GJ, Mahoney P, Hung NA, Sharma LA, Kalita P, et al. (2017) Osteoconduction in keratin-hydroxyapatite composite bone-graft substitutes. J Biomed Mater Res B Appl Biomater 105: 2034-2044. [Crossref]

5. Brazilian Animal Protein Association (2017) Anual report [online publication] Access in 07 sep 2018. Available from: http://abpa-br.com.br/storage/files/relatorioanual-2018.pdf.

6. Brazilian Meat Exporting Industries Association (2017) Brazilian cattle raising profile anual report [online publication]. Access in 07 sep 2018. Available from: http://gtps. org.br/wp-content/uploads/2017/08/Sumario_2017_screen.pdf.

7. Brazilian Fishery Association (2017) Anual report [online publication]. Access in 07 sep 2018. Available from: https://www.peixebr.com.br/.

${ }^{*}$ Correspondence to: Igor Iuco Castro-Silva, Postgraduate Program in Biotechnology, Federal University of Ceara (UFC), Avenida Maurocelio Rocha Pontes 100; Faculty of Dentistry, Federal University of Ceara (UFC), Rua Conselheiro Jose Julio, 62042-280, Sobral (CE), Brazil, E-mail: igor.iuco@sobral.ufc.br

Received: September 12, 2018; Accepted: September 26, 2018; Published: September 28, 2018 
Castro-Silva II (2018) Biotechnological potential of by-products of the Brazilian animal protein industry in the generation of xenogeneic biomaterials for bone regeneration

8. National Center for Biotechnology Information (NCBI) (2018) Bethesda (MD): National Library of Medicine (US), National Center for Biotechnology Information.

9. Sousa SB, Castro-Silva II, Coutinho LACR, Lenharo A, Granjeiro JM (2013) Osteoconduction and bioresorption of bone allograft versus anorganic bovine bone xenograft: a histomorphometric study in humans. J Biomim Biomater Tissue Eng 18: $85-95$.

10. Bittencourt RC, Castro-Silva II, Paulo AO, Tavares DS, Granjeiro JM (2014) Preclinical evaluation of a xenogenic hydroxyapatite/collagen-based bone substitute material. Rev odonto cienc 29: 6-13.
11. Gonçalves F, Hohn A, Granjeiro JM, Silva IIC, Taga R, Cestari TM, Zanetti RV, Zanetti AL (2009) Bone regeneration in dentistry with use of composed bone substitute Gen Mix. Implant News 6: 373-379.

12. Jardelino C, Takamori ER, Hermida LF, Lenharo A, Castro-Silva II, et al. (2010) Porcine peritoneum as source of biocompatible collagen in mice. Acta Cir Bras 25 332-336. [Crossref]

13. Diogo GS, López-Senra E, Pirraco RP, Canadas RF, Fernandes EM, Serra J, et al (2018) Marine collagen/apatite composite scaffolds envisaging hard tissue applications. Mar Drugs 16: 1-14.

Copyright: (C2018 Castro-Silva II. This is an open-access article distributed under the terms of the Creative Commons Attribution License, which permits unrestricted use, distribution, and reproduction in any medium, provided the original author and source are credited. 